\title{
EFEKTIVITAS STRATEGI PENGELOMPOKAN BERPASANGAN DALAM PEMBELAJARAN MATEMATIKA MODEL CORE
}

\author{
Endah Retnowati ${ }^{1)}$ dan Aqiilah ${ }^{2)}$ \\ ${ }^{1}$ Universitas Negeri Yogyakarta; ${ }^{2}$ Universitas Islam Negeri Walisongo \\ email: 'e.retno@uny.ac.id, 2qiel.aqilah@gmail.com
}

\begin{abstract}
Abstrak: Penelitian ini bertujuan untuk menguji keefektifan pembelajaran CORE (Connect, Organize, Reflect, Extend) pada pembelajaran geometri transformasi dengan strategi pengelompokan yang berbeda ditinjau dari kemampuan penalaran, prestasi, dan self efficacy. Penelitian ini merupakan penelitian eksperimen semu dengan populasi siswa kelas XI IPA SMA yang baru pertama kali mempelajari materi geometri transformasi. Sampel penelitian sebanyak dua kelas masing-masing terdiri atas 40 siswa. Siswa belajar dengan dikelompokkan secara berpasangan atau kelompok kecil. Data dikumpulkan dengan teknik tes dan nontes serta dianalisis dengan teknik statistik deskriptif dan inferensial (Manova). Hasil penelitian menunjukkan bahwa pembelajaran CORE strategi berpasangan maupun kelompok kecil efektif ditinjau dari Kriteria Ketuntasan Minimum kemampuan penalaran, prestasi dan self efficacy yang ditetapkan, tetapi tidak terdapat perbedaan yang signifikan di antara kedua strategi pengelompokan tersebut. Repeated measures analysis of variance menunjukkan bahwa kompleksitas materi pembelajaran memengaruhi prestasi belajar secara signifikan. Semakin kompleks materi pembelajaran, penggunaan strategi kelompok kecil lebih baik daripada berpasangan.
\end{abstract}

Kata kunci: CORE, kemampuan penalaran, prestasi belajar, self efficacy

\section{THE EFFECTIVENESS OF DYAD STRATEGY DURING MATHEMATICS LEARNING BASED ON CORE MODEL}

\begin{abstract}
The purpose of this study is to test the effectiveness of an instruction, namely CORE (Connect, Organize, Reflect, Extend) model, for learning geometry transformation in different grouping strategies (by dyads and small-group work), in terms of reasoning ability, achievement, and self-efficacy. This study was a quasi-experimental research with the entire population of science $11^{\text {th }}$ graders who were novices in geometry transformation. The research samples were two classes which respectively consist of 40 students. Students learned all material either in dyads or small groups. The results showed that CORE instruction model with dyads or small-group work strategies was effective in relation to students'reasoning ability, achievement, and self-efficacy. There was no significant difference between the two grouping strategies. The following repeated measured analysis of variance showed that complexity of learning material significantly affected learning achievement. It is concluded that when the learning material is high in complexity, learning it in small group is better than doing it in dyads.
\end{abstract}

Keywords: CORE, reasoning ability, achievement, self-efficacy

\section{PENDAHULUAN}

Matematika merupakan ilmu pengetahuan yang memegang peranan penting untuk menghadapi berbagai tantangan kehidupan. Matematika juga menjadi dasar bagi perkembangan ilmu pengetahuan yang lain, seperti yang dijelaskan dalam National Council of Teacher of Mathematics di USA (NCTM, 2000:66) bahwa: "mathematics is used in science, the social science, medicine and commerce". Dalam kehidupan sehari-hari, matematika juga dipakai untuk menghitung, menalar atau memecahkan masalah, sehingga matematika penting untuk dipelajari.

Pembelajaran matematika dipahami sebagai proses konstruktif untuk membangun konsepkonsep dan hubungan antar konsep (Steinbring, 2005: 87). Pembelajaran matematika melatih logika agar siswa berpikir secara runut, bernalar dan berargumen secara sistematis dan benar sesuai kerangka keilmuan matematika. Selain itu pembelajaran matematika juga bertujuan untuk meningkatkan pemahaman siswa terhadap fakta, konsep, 
prinsip dan kajian ilmu yang dipelajarinya, serta melatih kemampuan siswa dalam berpikir logis, kritis, dan kreatif (Muslih, 2011).

Pengalaman belajar matematika akan diperoleh siswa ketika pembelajaran lebih banyak melibatkan aktivitas siswa dalam proses pembelajaran. Dengan kata lain, siswa sebagai pusat pembelajaran (Westwood, 2008:14). Siswa didorong untuk aktif secara mental sehingga dapat mengkonstruksi dan mengembangkan pengetahuannya sendiri. Chambers $(2008: 100)$ menyatakan kegiatan pembelajaran matematika yang berpusat pada siswa dikembangkan berdasarkan konstruktivismedengan salah satu tokohnya adalah Jean Piaget. Hal ini diyakini oleh konstruktivisme akan memberikan pengalaman belajar yang lebih baik dan tidak mudah dilupakankarena secara langsung siswa terlibat aktif dalam pembelajaran dengan memberdayakan potensi pada diri siswa. Salah satu model pembelajaran ini adalah learning by CORE (Connect, Organize, Reflect, and Extend) (Calfee, Curwen, Miller, dan Smith, 2010). Calfee, dkk (2010) menyatakan bahwa CORE merupakan model pembelajaran yang dapat digunakan untuk semua siswa.

Model CORE merupakan salah satu model pembelajaran yang memberikan langkah yang baik karena mengintegrasikan berpikir kritis dan penalaran dalam pembelajaran matematika (Soule dan Wesolowski, 2011). Model pembelajaran CORE terdiri atas empat tahapan, yaitu Connect (menghubungkan pengetahuan), Organize (mengorganisasikan materi dengan membuat grafik atau peta konsep untuk mempermudah dalam mempelajari materi), Reflect (merefleksikan apa yang diperoleh pada tahap organize pada suatu hal yang sedang dipelajari serta memeriksanya kembali), dan Extend (memperdalam atau memperluas pengetahuan). Di setiap tahapan ini, siswa mempelajari pengetahuan matematika melalui memecahkan masalah.

Model pembelajaran CORE sangat berbeda dengan model pembelajaran langsung dengan metode ceramah konvensional yang saat ini masih banyak dipraktekkan oleh guru. Menggunakan metode ceramah konvensional, guru lebih banyak menjelaskan materi kepada seluruh siswa (Niken, Susanto dan Setiawan, 2012). Pembelajaran yang hanya satu arah seperti ini disebut pembelajaran yang berpusat pada guru (teacher center). Dalam hal ini guru dianggap kurang dalam memfasilitasi siswa untuk mencari dan memahami pengetahuan karena guru cenderung memberikan informasi dan pengetahuan kepada siswa secara langsung. Sehingga pengalaman belajar siswa yang mandiri masih kurang dan mungkin juga terjadi potensi siswa yang tidak menjadi perhatian dari guru.

Prestasi belajar matematika dapat dimaknai sebagai hasil yang dicapai siswa selama proses berlangsungnya pembelajaran matematika dalam kurun waktu tertentu, yang umumnya ditandai dengan pemberian nilai (Muslimin, 2012:382). Nilai yang diperoleh siswa dapat diketahui dari seberapa banyak indikator kompetensi yang mampu dicapai oleh siswa. Untuk dapat mengetahui hasil dari prestasi belajar siswa, maka digunakan alat ukur yang disebut tes prestasi belajar. Tes prestasi belajar dirancang untuk mengukur tingkat pembelajaran yang telah berlangsung setelah seseorang mengalami proses pembelajaran (Johnson dan Christensen, 2014:117).

Syah (1995:132) mengemukakan bahwa faktor-faktor yang memengaruhi prestasi belajar siswa ada tiga, yaitu: a) faktor internal (faktor dari dalam siswa), yakni keadaan atau kondisi jasmani dan rohani siswa; b) faktor eksternal (faktor dari luar siswa), yakni kondisi lingkungan di sekitar siswa; serta c) faktor pendekatan belajar (approach to learning), yakni jenis upaya belajar siswa yang meliputi strategi dan metode yang digunakan siswa untuk melakukan kegiatan pembelajaran materi-materi pelajaran. Ketiga faktor tersebut memengaruhi siswa mencapai tujuan pembelajaran, baik dalam domain kognitif, afektif, maupun psikomotorik.

Banyak faktor yang harus dikenali oleh guru terhadap siswa selama proses pemeblajaran, salah satunya adalah faktor psikologis dalam diri siswa. Bandura (1997) mendefinisikan self efficacy sebagai faktor psikologis berupa keyakinan siswa untuk dapat berhasil menyelesaikan suatu masalah. Keyakinan belajar membangun motivasi instrinsik siswa untuk gigih dalam belajar (Bruning, Schraw, dan Norby, 2011). Self efficacy tampaknyamasih kurang mendapatkan perhatian yang serius dari kebanyakan guru. Hal ini dikarenakan fokus tujuan pembelajaran pada umumnya adalah prestasi siswa atau cenderung mengejar materi-materi pembelajaran yang diujikan pada tes terstandarisasi seperti Ujian Nasional, bukan pada membangun keyakinan untuk belajar.

Sejalan dengan Bandura, menurut McKinley (2010:2), rendahnya prestasi belajar dapat disebabkan karena rendahnya self-efficacy, yang 
mungkin disebabkan oleh rendahnya hubungan interpersonal, kurangnya umpan balik dan kesempatan belajar selama proses pembelajaran. Untuk lebih mengoptimalkan self efficacy siswa, guru dapat melakukan inovasi model pembelajaran atau menggunakan media tertentu yang lebih banyak melibatkan kegiatan siswa sehingga bisa membantu siswa dalam mengoptimalkan self efficacy-nya. Putri (2014) menggunakan model pembelajaran REACT dikatakan mampu meningkatkan self efficacy siswa; Saputra (2016) dalam salah satu hasil penelitiannya juga menyebutkan bahwa pembelajaran geometri dengan menggunakan media Geogebra efektif meningkatkan self efficacy.

Self efficacy dapat diidentifikasi sebagai salah satu faktor yang paling kuat dari proses pengaturan diri (Maltby, Day dan Macaskill, 2010:98). Hal ini juga berpengaruh pada apa yang kita pilih untuk dikerjakan dan seberapa besar usaha kita serta bagaimana kita bertahan untuk bisa menyelesaikannya (Lefrancois, 2000:423). Berkaitan dengan matematika, disebutkan oleh Sengul (2011: 2305) bahwa mathematics self efficacy adalah kepercayaan seseorang akan kemampuannya untuk dapat berhasil melakukan hingga menyelesaikan tugas-tugas matematika. Mathe-matics self efficacy berkorelasi positif dengan prestasi matematika. Bandura (1997) mengemukakan bahwa dimensi self efficacy meliputi tiga elemen, yaitu magnitude yang berkaitan dengan tingkat (level) kesulitan tugas. Generality yang merupakan keyakinan akan kemampuan yang ditunjukkan individu pada konteks tugas yang berbeda dan strength yang merupakan kuatnya keyakinan seseorang berkenaan dengan kemampuan, ketahan dan keuletan individu/siswa dalam pemenuhan tugas.

Model pembelajaran CORE yang telah dijelaskan di atas diduga mampu memfasilitasi siswa dalam proses pembelajaran matematika dengan baik, sehingga mampu meningkatkan potensi serta membentuk sikap yang baik pada diri siswa. Model pembelajaran tersebut telah diterapkan dalam beberapa pembelajaran matematika oleh para peneliti. Penelitian yang dilakukan Beladina, Suyitno dan Kusni (2013) menjelaskan bahwa pembelajaran dengan menggunakan CORE dapat meningkatkan kreativitas siswa pada pembelajaran segitiga, sementara itu Al-humaira, Suherman dan Jazwinarti (2013) membuktikan bahwa model CORE dapat meningkatkan kemampuan komunikasi.
Kemampuan penalaran menjadi elemen kunci dari matematika yang merupakan bagian penting dalam pembelajaran matematika di sekolah. Kemampuan penalaran sangat dibutuhkan pada saat menyelesaikan masalah matematika karena kemampuan penalaran dan matematika adalah dua aspek yang saling terkait. Misalnya dalam pembelajaran geometri transformasi meliputi translasi, refleksi, rotasi dan dilatasi (Albab, Hartono dan Darmawijoyo, 2014), kemampuan penalaran dibutuhkan oleh siswa karena dalam pembelajaran ini siswa diarahkan untuk bisa memahami pola, membuat dugaan, menyusun jawaban dengan argumen yang tepat sesuai dengan perintah soal yang juga melibatkan penalaran. Dalam pembelajaran ini siswa juga harus mampu menerapkan konsep yang telah diperoleh sebelumnya seperti matriks, vektor dan trigonometri untuk selanjutnya bisa diterapkan dalam konsep dalam mempelajari geometri transformasi.

Model CORE dilakukan dalam kelompokkelompok kecil (small group work) yang terdiri dari 4-5 orang. Strategi pengelompokan lain yang juga dapat dilakukan oleh guru dalam pembelajaran adalah dengan mengelompokkan siswanya secara berpasangan atau dyads method (Dzhogleva dan Lamberton, 2014). Pengelompokan dengan cara ini akan lebih cepat dibentuk karena bisa lakukan dengan teman sebangkunya, serta membuat siswa lebih fokus dalam berdiskusi karena lebih sedikit gangguan jika dibandingkan dengan jumlah anggota kelompok yang lebih banyak.

Salah satu faktor yang menyebabkan gangguan interaksi siswa dalam kelompok adalah social loafing (Latane, Williams, dan Harkin, 1979:823), yang didefinisikan sebagai suatu hal yang menyebabkan upaya dan motivasi seseorang berkurang atau menurun karena adanya orang lain dalam suatu kelompok. Semakin banyak anggota kelompok, semakin besar gangguan social loafing. Oleh karena itu, apabila pembelajaran dilakukan dalam berkelompok, perlu ada metode yang meminimalkan munculnya social loafing.

Diskusi kelompok juga dipengaruhi oleh seberapa kompleks materi yang disajikan (Cohen, 1994). Materi dengan kompleksitas tinggi akan lebih baik dikerjakan secara berkelompok sedangkan materi dengan kompleksitas rendah akan lebih efektif jika dilakukan secara individu (Kirschner, Paas dan Kirschner, 2010). Menurut Cohen, materi yang disajikan dalam kelompok sebaiknya materi yang memiliki kompleksitas tinggi. Menurut 
Kirschner, Sweller dan Clark (2006), kelompok belajar biasanya difasilitasi dengan materi kontekstual atau melalui studi kasus. Selain itu, siswa dalam kelompok perlu diatur sedemikian sehingga tidak hanya secara fisik saja berkelompok, tetapi dapat sa-ling bertukar pengetahuan untuk menyelesaikan masalah bersama-sama.Oleh karena itu, perlu penelitian untuk mendapatkan bukti-bukti empiris bagaimana strategi pengelompokan yang efektif dan efisien.

Penelitian ini bertujuan untuk mengetahui keefektifan model pembelajaran CORE dalam pembelajaran geometri transformasi dengan strategi pengelompokan yang berbeda yaitu kelompok kecil (group work) dan berpasangan (dyads) ditinjau dari kemampuan penalaran, prestasi belajar serta self efficacy siswa, yang kemudian dibandingkan manakah yang lebih baik diantara keduanya. Selain itu penelitian ini juga akan melihat pengaruh kompleksitas materi terhadap prestasi belajar sehingga dapat menjadi referensi dalam melaksanakan pembelajaran.

Hipotesis yang diuji: (1) model pembelajaran CORE strategi berpasangan pada pembelajaran geometri transformasi efektif ditinjau dari Kriteria Ketuntasan Minimal (KKM) kemampuan penalaran, self efficacy atau prestasi belajar siswa; (2) model pembelajaran CORE strategi kelompok kecil pada pembelajaran geometri transformasi efektif ditinjau dari Kriteria Ketuntasan Minimal (KKM) kemampuan penalaran, self efficacy atau prestasi belajar siswa; (3) model pembelajaran CORE strategi berpasangan lebih efektif dibandingkan dengan model pembelajaran CORE strategi kelompok kecil pada pembelajaran geometri transformasi ditinjau dari kemampuan penalaran, self efficacy dan prestasi belajar siswa; (4) ada pengaruh kompleksitas materi terhadap keefektifan model pembelajaran CORE ditinjau dari prestasi belajar siswa.

\section{METODE}

Penelitian ini berjenis penelitian eksperimen semukarena beberapa variabel tidak bisa terkontrol seperti pengontrolan secara penuh pada penelitian eksperimen murni. Selain itu, randomisasi anggota kelompok eksperimen dilakukan tidak sepenuhnya karena menggunakan seting alami lingkungan sekolah. Penentuan kelas eksperimen dilakukan dengan mengundi secara acak lima kelas yang ada untuk diambil dua kelas eksperimen, kemudian diundi lagi untuk menentukan kelas mana yang akan diterapkan pembelajaran menggunakan pembelajaran CORE strategi berpasangan dan pembelajaran CORE strategi kelompok kecil.

Penelitian ini dilaksanakan di kelas XI jurusan MIPA SMANegeri di Jawa Tengah, tahun ajaran 2015/2016. Populasi dalam penelitian ini adalah seluruh siswa kelas XI MIPA SMA yang belum pernah mempelajari materi geometri transformasi, khususnya translasi, refleksi, rotasi dan dilatasi. Penelitian ini menggunakan dua kelas yang setara ditinjau dari guru yang mengajar, sumber belajar yang digunakan, banyaknya siswa, jenis kelamin siswa, pembagian siswa acak sejak awal sekolah, ruang kelas dan jam pelajaran. Dua kelas eksperimen akan diberikan perlakuan yaitu satu kelas dengan model pembelajaran CORE strategi kelompok kecil dan satu kelas dengan pembelajaran CORE strategi berpasangan.

Desain penelitian yang digunakan adalah pretest-posttest nonequivalent comparison-group design (Johnson dan Christensen, 2014:256) dengan melibatkan dua kelompok eksperimen yang masing-masing mendapatkan perlakuan berbeda. Langkah-langkah yang dilakukan dalam penelitian eksperimen berupa: (1) memberikan pre-test (tes awal) terhadap dua kelompok tersebut, (2) melakukan pembelajaran dengan model pembelajaran CORE strategi kelompok kecil pada kelompok eksperimen 1 dan CORE strategi berpasangan pada kelompok eksperimen 2, dan (3) memberikan post-test (tes akhir) pada kedua kelompok.

Penelitian ini melibatkan tiga variabel terikat (dependent variable) dan dua variabel bebas (independent variable).Variabel terikat dalam penelitian ini adalah (1) prestasi Belajar geometri transformasi, (2) kemampuan penalaran, dan (3) self-efficacy.Prestasi belajar geometri transformasi secara operasional dapat dilihat dari ketercapaian indikator pencapaian kompetensi yang dikembangkan sesuai dengan kompetensi yang dipelajari selama pembelajaran geometri transformasi kelas-kelas eksperimen.

Kemampuan penalaran matematika adalah kemampuan siswa untuk dapat menyelesaikan permasalah secara logis, menemukan dan menggeneralisasi pola, membuat dugaan, serta menjawab/menyusun argumen secara logis dan mampu membuat kesimpulan. Soal yang dibuat untuk mengukur kemampuan penalaran yaitu soal yang mencakup aspek kemampuan penalaran, 
yaitu kemampuan siswa untuk dapat menyusun argumen secara logis, kemampuan menemukan pola, kemampuan menggeneralisasi pola, serta membuat dugaan matematika.

Self efficacy merupakan salah satu faktor yang berpengaruh pada siswa. Self efficacy terhadap matematika adalah persepsi tentang keyakinan akan kemampuan diri siswa dalam mengatur dan menyelesaikan tugas serta keyakinan diri dalam berusaha mencapai tujuan tertentu yang dalam hal ini adalah prestasi belajar matematika. Aspek dalam self efficacy meliputi 3 aspek yang kemudian dikembangkan menjadi 6 indikator, yang dikembangkan berdasarkan kajian teori self efficacy oleh Bandura (1997), seperti dapat dilihat pada Tabel 1.

Pengumpulan data menggunakan teknik tesdan nontes. Teknik tes terdiri atas pre-tes dan post-tes. Masing-masing terdiri dari dua tes, yaitu tes uraian untuk mengukur kemampuan penalaran dan pilihan ganda untuk mengukur prestasi belajar siswa yang memuat seluruh kompetensi yang dipelajari siswa. Validitas tes prestasi belajar yang berupa pilihan ganda serta tes kemampuan penalaran yang berupa uraian dilakukan dengan melihat validitas isi yang diperoleh lewat pendapat dua orang ahli. Tes prestasi belajar juga dianalisis butir soalnya untuk melihat reliabilitas dan tingkat kesukaran dari tiap butir soalnya dari hasil uji coba tes. Teknik nontes dilakukan lewat angket (20 pernyataan dengan skala Likert) untuk mengetahui tingkat self efficacy siswa. Validitas dilakukan dengan melihat validitas isi dan validitas konstruk dengan cara expertjudgment. Selanjutnya, dilakukan analisis faktor untuk memperoleh validitas konstruk dan diperoleh nilai Kaiser-Meyer-Olkin (KMO) sebesar 0,773 dengan banyak komponen yang terbentuk sebanyak enam komponen.

Hasil analisis menunjukkan bahwa koefisien reliabilitas (KR-21) untuk pre-test dan post-test perstasi belajar berturut-turut sebesar
0,672 dan 0,644, adapun untuk pre-tes dan posttest kemampuan penalaran (Cronbach's Alpha) berturut-turut sebesar 0,739 dan 0,759 sedangkan untuk reliabilitas angket self efficacy diperoleh sebesar 0,891 .

Data yang berkaitan dengan prestasi belajar matematika dideskripsikan dari nilai yang diperoleh siswa berdasarkan hasil tes prestasi belajar matematika materi geometri transformasi. Data yang berkaitan dengan kemampuan penalaran dideskripsikan dari skor yang diperoleh siswa dari tes kemampuan penalaran. Adapun untuk data yang berkaitan dengan self efficacy siswa, dideskripsikan dari jumlah skor angket self effica$c y$ siswa dalam proses pembelajaran matematika yang diperoleh siswa yang kemudian dikategorikan berdasarkan skor baku yang telah dikonversi. Untuk menentukan kategori hasil pengukurannya digunakan klasifikasi yang ditentukan dengan rata-rata ideal dan standar deviasi ideal menurut Azwar (2015:163) yang dapat dilihat pada Tabel 2.

Tabel 2. Konversi Data Kualitatif ke Kuantitatif

\begin{tabular}{cc}
\hline Interval Skor $(X)$ & Kategori \\
\hline $120<X \leq 150$ & Sangat tinggi \\
$100<X \leq 120$ & Tinggi \\
$80<X \leq 100$ & Sedang \\
$60<X \leq 80$ & Rendah \\
$30<X \leq 60$ & Sangat rendah \\
\hline
\end{tabular}

Data yang diperoleh dari hasil penelitian tersebut kemudian dianalisis untuk diketahui keefektifannya dan kemudian dilakukan perbandingan antara dua kelompok pembelajaran tersebut. Sebelum dilakukan uji analisis keefektifan, terlebih dahulu dilakukan uji asumsi data yang meliputi asumsi kenormalan multivariat menggunakan uji jarak mahalanobis dengan melihat scatter plot antara $d_{i}^{2}$ antara setiap pengamatan dengan

Tabel 1. Aspek dan indikator self efficacy

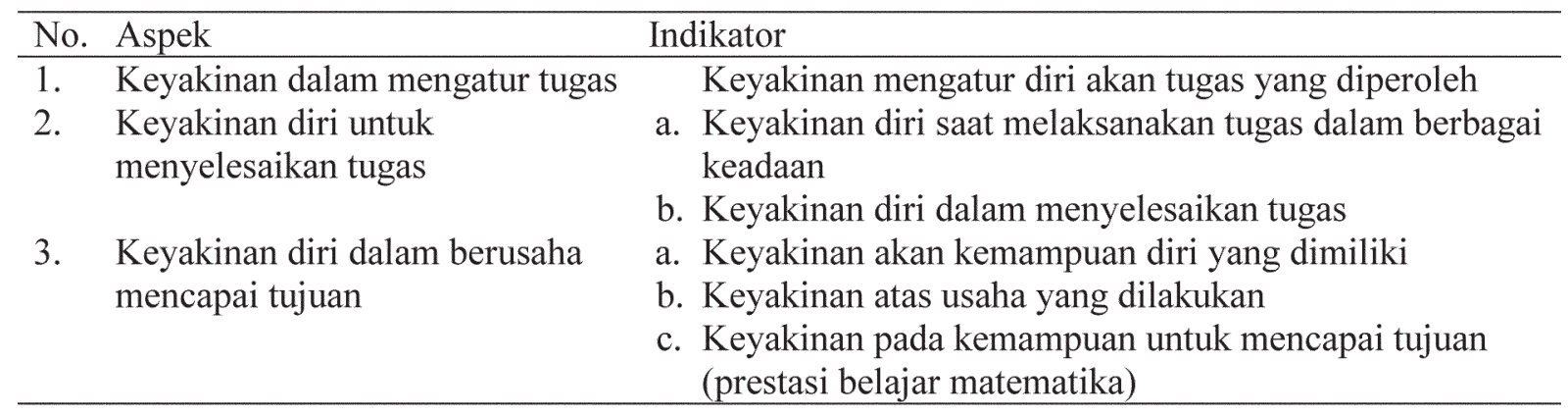


vektor rata-rata setelah diurutkan, adapun untuk asumsi homogenitas multivariat dengan melihat nilai signfikansi dari Box ' $M$. Uji keefektifan dari masing-masing pembelajaran yang ditinjau dari variabel terikatnya dilakukan dengan uji one sample t-test. Selanjutnya untuk mengetahui kelompok belajar mana yang lebih efektif dilakukan uji MANOVA(kriteria Hotelling's Trace) dengan kriteria keputusan pada taraf signifikansi 5\% dengan melihat terlebih dahulu kondisi kemampuan awal pada dua kelas tersebut.

Untuk data prestasi belajar yang diperoleh secara berulang, selanjutnya dilakukan uji pengukuran berulang untuk melihat perbedaan keefektifan model CORE yang dilakukan pada setiap pembelajaran yang dilihat dari hasil tes di akhir pembelajaran. Uji ini dilakukan dengan perhitungan Repeated Measured Anova.

\section{HASIL DAN PEMBAHASAN Hasil}

Data yang diperoleh dalam penelitian ini berupadata prestasi yang diukur secara berulang dengan lima kali post-test, data kemampuan penalaran dan data self efficacy siswa. Berikut berturut-turut disajikan deskripsi data masing-masing variabel yang dapat dilihat pada Tabel 3 .

Adapun jika diperinci hasil pada setiap post-test diberikan di setiap akhir pembelajaran dapat dilihat pada Tabel 4.

Tabel 4 memberikan informasi bahwa pada setiap post-test yang diberikan, pada kelas dengan pembelajaran model CORE strategi kelompok kecil terjadi peningkatan rata-rata jika dibandingkan dengan pre-test nya dan masing-masing lebih dari 72 , kecuali pada post-test yang kedua yang diberikan setelah pembelajaran refleksi yang hanya mempunyai rata-rata 71 , hal ini dikarenakan materi refleksi merupakan materi yang paling banyak diantara materi lain, karena materi ini melibatkan banyak sumbu refleksi. Selanjutnya untuk deskripsi hasil prestasi belajar di setiap post-test yang diberikan pada kelas dengan pembelajaran model CORE strategi berpasangan dapat dilihat pada Tabel 5 .

Tabel 5 memberikan informasi bahwa pada setiap post-test yang diberikan pada kelas dengan model CORE strategi berpasangan terjadi peningkatan rata-rata jika dibandingkan dengan pre-test nya dan masing-masing lebih dari 72 , kecuali pada post-test yang kedua yaitu refleksi yang hanya mempunyai rata-rata 71,5 . Selanjutnya untuk data tentang kemampuan penalaran dapat dilihat pada Tabel 6 .

Untuk deskripsi data self efficacy siswa dapat dilihat pada Tabel 7. Berdasarkan data pada Tabel 7, skor rata-rata kelompok CORE strategi kelompok kecil meningkat sebesar 10,55 yaitu dari 94,63 dengan kategori sedang menjadi 105,18 dengan kategori tinggi, sedangkan pada kelompok CORE strategi berpasangan nilai rata-rata meningkat sebesar 12,77 yaitu dari skor ratarata awal 95,58 dengan kategori sedang menjadi 108,35 dengan kategori tinggi.

Distribusi frekuensi self efficacy siswa yang diperoleh sebelum (pre-test) dan setelah perlakuan (post-test) sesuai dengan kriteria dari sangat rendah ke sangat tinggi dapat dilihat pada Tabel 8.

Diperoleh informasi bahwa pada kelompok model pembelajaran CORE strategi kelompok kecil sebanyak 6 siswa mengalami peningkatan

Tabel 3. Deskripsi Data Prestasi Belajar Siswa

\begin{tabular}{ccccc}
\hline Deskripsi & \multicolumn{2}{c}{ Pre-Test } & \multicolumn{2}{c}{ Post-Test } \\
& Kelompok kecil & Berpasangan & Kelompok kecil & Berpasangan \\
\hline Means & 41,63 & 42,50 & 80,46 & 78,35 \\
Maks & 50 & 45 & 100 & 96,8 \\
Min & 30 & 35 & 65 & 62,2 \\
St.dev & 4,72 & 3,24 & 7,93 & 6,72 \\
\hline
\end{tabular}

Tabel 4. Deskripsi Data Prestasi Belajar Siswa CORE Kelompok Kecil

\begin{tabular}{ccccccc}
\hline \multirow{2}{*}{ Des-kripsi } & \multirow{2}{*}{ Pre-test } & \multicolumn{5}{c}{ Post-test } \\
\cline { 3 - 7 } & & 1 & 2 & 3 & 4 & 5 \\
\hline Mean & 41,63 & 85,15 & 71,00 & 81,83 & 85,98 & 78,35 \\
Maks & 50 & 100 & 100 & 100 & 100 & 100 \\
Min & 30 & 67 & 40 & 33 & 67 & 50 \\
St.dev & 4,72 & 16,63 & 14,99 & 18,30 & 16,52 & 12,18 \\
\hline
\end{tabular}


Tabel 5. Deskripsi Data Prestasi Belajar Siswa CORE Berpasangan

\begin{tabular}{ccccccc}
\hline \multirow{2}{*}{ Deskripsi } & \multirow{2}{*}{ Pre-test } & \multicolumn{5}{c}{ Post-test } \\
\cline { 3 - 7 } & & 1 & 2 & 3 & 4 & 5 \\
\hline Mean & 41,50 & 83,50 & 71,50 & 80,18 & 78,55 & 78,00 \\
Maks & 45 & 100 & 100 & 100 & 100 & 100 \\
Min & 35 & 67 & 40 & 33 & 67 & 50 \\
St.dev & 3,24 & 16,71 & 12,72 & 18,06 & 15,94 & 10,47 \\
\hline
\end{tabular}

Tabel 6. Deskripsi Data Kemampuan Penalaran

\begin{tabular}{ccccc}
\hline \multirow{2}{*}{ Deskripsi } & \multicolumn{2}{c}{ Pre-Test } & \multicolumn{2}{c}{ Post-Test } \\
\cline { 2 - 5 } & Kelompok kecil & Berpasangan & Kelompok kecil & Berpasangan \\
\hline Mean & 18,54 & 17,71 & 76,46 & 74,51 \\
Maks & 27,78 & 25,00 & 94,44 & 88,89 \\
Min & 11,11 & 11,11 & 61,11 & 55,56 \\
St.dev & 4,28 & 3,31 & 7,25 & 7,33 \\
\hline
\end{tabular}

Tabel 7. Deskripsi Data Self Efficacy

\begin{tabular}{ccccc}
\hline Deskripsi & \multicolumn{2}{c}{ Pre-Test } & \multicolumn{2}{c}{ Post-Test } \\
\cline { 2 - 5 } & Kelompok kecil & Berpasangan & Kelompok kecil & Berpasangan \\
\hline Mean & 94,63 & 95,58 & 105,18 & 108,35 \\
Maks & 115 & 110 & 126 & 137 \\
Min & 75 & 75 & 81 & 93 \\
St.dev & 9,47 & 8,16 & 11,76 & 10,43 \\
\hline
\end{tabular}

Tabel 8.DeskripsiFrekuensi Banyaknya Siswa Dalam KriteriaSelf Efficacy

\begin{tabular}{ccccc}
\hline \multirow{2}{*}{ Kriteria } & \multicolumn{2}{c}{ Pre-Test } & \multicolumn{2}{c}{ Post-test } \\
\cline { 2 - 5 } & Kelompok kecil & Berpasangan & Kelompok kecil & Berpasangan \\
\hline Sangat Tinggi & $\mathbf{0}$ & $\mathbf{0}$ & $\mathbf{6}$ & $\mathbf{8}$ \\
Tinggi & $\mathbf{1 2}$ & $\mathbf{1 4}$ & $\mathbf{1 9}$ & $\mathbf{2 2}$ \\
Sedang & 25 & 24 & 15 & 10 \\
Rendah & 3 & 2 & 0 & 0 \\
Sangat Rendah & 0 & 0 & 0 & 0 \\
\hline
\end{tabular}

ke level self efficacy kategori sangat tinggi dan 8 siswa meningkat ke level self efficacy kategori tinggi. Sementara pada kelompok model pembelajaran CORE strategi berpasangan sebanyak 8 siswa meningkat ke level self efficacy kategori sangat tinggi dan 8 siswa meningkat ke level self efficacy kategori tinggi.

\section{Pembahasan}

Ada empat hipotesis penelitian yang dibuktikan melalui uji hipotesis yang diuraikan dan dibahas sebagai berikut. Sebelumnya, hasil uji asumsi dari data yang diperoleh menunjukkan bahwa data hasil penelitian memenuhi asumsi normalitas dan homogenitas secara multivariat dan juga univariat. Sebelum dilakukan uji keefek- tifan, dilakukan analisis data sebelum diberikan perlakuan untuk dilihat perbedaan kemampuan awalnya, yang diuji dengan MANOVA. Diperoleh $F(3,76)=0,758$ dengan $p=0,521>0,02$, partial $\eta=0,029$. Hal ini mengindikasikan bahwa kondisi awal kedua kelompok untuk semua aspek yang diukur sama.

Kriteria keefektifan pendekatan pembelajaran yang digunakan dalam penelitian ini adalah untuk prestasi belajar matematika menggunakan kriteria ketuntasan minimal (KKM) yang telah ditetapkan tempat penelitian yaitu 72 , dan untuk kemampuan penalaran ditetapkan sama dengan KKM prestasi belajar, yaitu 72, sedangkan KKMself efficacy siswa menggunakan batas bawah kriteria tinggi (Tabel 2). 
Selanjutnya untuk hasil uji keefektifan pembelajaran model CORE strategi kelompok kecil ditinjau dari Kriteria Kelulusan Minimal $(\mathrm{KKM})$ (Hipotesis 1), diperoleh nilai $t(39)=6,826$ dengan $p=0,000$ pada aspek prestasi belajar, pada aspek kemampuan penalaran diperoleh $t(39)=3,974$ dengan $p=0,000$, dan pada aspek self efficacy diperoleh $t(39)=2,784$ dengan $p=0,008$. Dari hasil tersebut diketahui bahwa nilai signifikansi $t$ untuk semua aspek jika dibagi dua nilainya lebih kecil dari 0,05. Hal ini mengindikasikan bahwa pembelajaran dengan model CORE strategi kelompok kecil efektif ditinjau dari ketiga aspek tersebut.

Hasil penelitian membuktikan hipotesis yang diajukan. Hasil penelitian ini juga membuktikan teori dari Calfee, dkk (2010) yang menyatakan bahwa model CORE merupakan suatu basis pembelajaran yang digunakan untuk semua pembelajaran dengan memperhatikan pada pendekatan kognitif. Selain itu Soule dan Wesolowski (2011) juga mengatakan bahwa model CORE dapat membantu siswa untuk melatih penalaran. Strategi pengelompokan dalam 3-6 orang juga memengaruhi hasil yang diberikan, karena menurut Gillies (2003), siswa lebih termotivasi untuk mencapai pembelajaran ketika bekerja dalam kelompok sebagai rekan bekerja dibandingkan secara individual.

Pembelajaran model CORE melibatkan banyak aktivitas siswa disetiap tahapannya, sehingga akan lebih memunculkan self efficacy dalam menyelesaikan masalah karena siswa sendiri yang menyusun pengetahuan dan memperoleh pengalaman belajarnya melalui tahapan pada model CORE. Seperti yang diungkapkan Schunk (2012: 147) siswa dengan self efficacy yang tinggi cenderung tertarik dalam mengerjakan soal yang diberikan dengan tingkat kesulitan tertentu dan akan mencoba mengerjakan kembali ketika masih menemukan kesalahan, dan sebaliknya siswa yang mempunyai efficacy diri yang rendah akan menghindari menyelesaikan soal yang diberikan terutama jika tingkat kesulitan semakin kompleks.

Hasil uji keefektifan pembelajaran model CORE strategi berpasangan ditinjau dari Kriteria Kelulusan Minimal (KKM) (Hipotesis 2), diperoleh nilai $t=(39)=6,063$ dengan $p=0,000$ pada aspek prestasi belajar, pada aspek kemampuan penalaran diperoleh $t(39)=2,255$ dengan $p=0,030$, dan pada aspek self efficacy diperoleh $t(39)=5,062$ dengan $p=0,000$. Dari hasil tersebut diketahui bahwa nilai signifikansi $t$ untuk semua aspek jika dibagi dua nilainya lebih kecil dari 0,05 . Hal ini mengindikasikan bahwa pembelajaran dengan model CORE strategi berpasangan efektif ditinjau dari ketiga aspek tersebut.

Hasil penelitian sesuai dengan hipotesis yang disusun di awal. Model CORE efektif ditinjau dari prestasi, kemampuan penalaran dan self efficacy siswa. Pada kelas ini siswa dikelompokkan secara berpasangan, hal ini akan lebih memusatkan perhatian siswa ketika berdiskusi dalam pembelajaran. hal ini sesuai dengan penelitian yang dilakukan oleh Dzhogleva dan Lamberton (2014), yang menyatakan bahwa pembagian kelompok secara berpasangan akan membuat kontrol diri siswa lebih tinggi, membuat dan menjadikan siswa yang lebih aktif.

Penelitian yang dilakukan Steenbeek dan Geert pada tahun 2006 juga menyatakan bahwa pembelajaran berpasangan lebih baik dalam aspek perhatian (yang meliputi niat, tujuan dan kepentingan), penilaian dan penularan yang memusatkan hanya pada dua siswa. Lebih lanjut Latane, dkk (1979) dalam penelitiannya memperoleh hasil bahwa siswa yang bekerja dalam kelompok berpasangan menghasilkan usaha yang lebih baik dari setiap individu dibandingkan dengan siswa yang bekerja pada kelompok yang lebih banyak anggotanya.

Untuk melihat perbedaan keefektifan kedua kelompok ditinjau dari ketiga variabel terikat (Hipotesis 3) dilakukan uji menggunakan MANOVA yang hasilnya diperoleh $3,76=1,520$ dengan $p=0,216>0,05$, partial $\eta^{2}=0,057 \mathrm{Hal}$ ini mengindikasikan bahwa tidak terdapat perbedaan keefektifan antara pembelajaran dengan model CORE strategi kelompok kecil maupun strategi berpasangan, artinya pembelajaran CORE tidak membedakan hasil meskipun dilakukan pengelompokan dengan anggota antara 2 sampai 6 siswa. Hal ini tidak sejalan dengan hipotesis penelitian. Model CORE pada kedua kelas mempunyai keefektifan yang sama, artinya tidak ada pengaruh strategi pengelompokan pada keduanya. Hal ini diduga karenapada strategi kelompok kecil ide yang muncul lebih banyak (Gillies, 2003) dengan cara berkolaborasi dalam kelompok (Retnowati, Ayres dan Sweller, 2010: 351) dapat memfasilitasi pemahaman. Adapun pada strategi berpasangan perhatian lebih terpusat pada pemahaman materi dan munculnya social loafing berkurang sehingga 
usaha yang dilakukan akan lebih maksimal (Latane, dkk, 1979).

Analisis selanjutnya untuk data prestasi belajar yang diukur secara berulang, pada variabel jenis materi pembelajaran diperoleh nilai $F(4,75)=13,845$ dengan $p=0,000<\eta^{2}=0,418$, partial memengaruhi prestasi belajar siswa. Hal ini sesuai dengan hipotesis penelitian (Hipotesis 4). Effect size partial sebesar 0,418 yang artinya bahwa materi memberikan pengaruh terhadap setiap post-test yang diberikan pada setiap pertemuan dengan materi yang berbeda sebesar $41,8 \%$. Namun, tidak ditemukan interaction effect antara jenis materi dan strategi pengelompokan diperoleh nilai $4,75=0,782$ dengan $p=0,541>0,05$, partial $\eta^{2}=0,040$. Hal ini mengindikasikan bahwa strategi pengelompokan tidak memberikan pengaruh yang berbeda di setiap post-test dengan materi berbeda. Hasil ini sejalan hasil uji perbedaan keefektifan pembelajaran yang diuji dengan MANOVA di atas bahwa memang tidak ada perbedaan efek dari strategi pengelompokan.

Lebih lanjut untuk mempelajari bukti empiris lebih mendalam juga dilakukan analisis untuk dilihat interaksi pengelompokan dengan setiap materi yang diberikan dengan uji independent sample t-test, yang hasilnya diperoleh bahwa hanya ada interaksi pengelompokan pada materi dilatasi saja (satu dari 5 jenis materi yang ada) sementara untuk jenis materi yang lain tidak terdapat interaksi. Hal ini diketahui pada materi dilatasi diperoleh nilai $t(78) 2,046$ dengan $p=0,044<0,05$. Materi dilatasi diberikan mendekati akhir pembelajran geometri transformasi. Materi ini diberikan setelah materi translasi, refleksi dan rotasi. Pada materi ini tingkat kompleksitasnya tergolong tinggi karena pada materi dilatasi ada dua hal yang perlu diperhatikan yaitu faktor skala yang bermacam-macam, yaitu untuk $k>1,0<k$, $-1<k<0, k<-1$ dan $k=-1$ serta dua macam pusat dilatasi yaitu di titik $(0,0)$ dan di titik $(a, b)$. Hal inilah yang diduga menjadikan adanya interaksi antara pengelompokan dengan materi dilatasi. Hasil yang diperoleh menunjukkan bahwa pada strategi kelompok kecil memungkinkan lebih baik daripada strategi berpasangan pada jenis materi yang lebih kompleks. Hal ini sesuai dengan hasil penelitian Kirschner, Paas, dan Kirschner (2010) bahwa materi dengan kompleksitas tinggi akan lebih baik dikerjakan secara berkelompok karena ide yang muncul akan lebih banyak. Pada materi refleksi meskipun ukuran sumbu refleksi yang dibahas cukup banyak, sehingga tingkat kompleksitasnya juga tinggi, namun pada pelaksanaannya pembelajaran hanya membahas 3 sumbu refleksi saja, tidak secara keseluruhan dikerjakan oleh setiap kelompok, sehingga hal ini diduga menjadikannya kurang kompleks. Oleh karena itu, untuk jenis materi ini tidak ada perbedaan secara signifikan pengelompokan secara berpasangan dan kelompok kecil.

Temuan dalam penelitian ini menyatakan bahwa tidak terdapat perbedaan secara signifikan antara model pembelajaran CORE yang dilakukan dalam strategi kelompok kecil maupun berpasangan ditinjau dari kemampuan penalaran, prestasi dan self efficacy. Lebih lanjut diketahui bahwa yang menyebabkan perbedaan adalah kompleksitas materi pembelajaran yang diberikan, hal ini sesuai dengan penelitian Kirschner, Paas, dan Kirschner (2010). Kompleksitas materi pembelajaran dapat dilihat dari materi prasyarat yang harus dikuasai siswa untuk bisa mempelajarinya. Pengaruh pengelompokan hanya terjadi pada materi dilatasi yang materinya tergolong kompleks sehingga menunjukkan perbedaan yang signifikan di antara dua kelompok tersebut. Semakin kompleks materi pembelajaran akan lebih baik dikerjakan dalam kelompok kecil dibandingkan dengan berpasangan.

\section{SIMPULAN}

Berdasarkan hasil pengujian hipotesis dan pembahasan, diperoleh simpulan sebagai berikut: (1) pembelajaran model CORE strategi kelompok kecil pada materi geometri transformasi efektif ditinjau dari kemampuan penalaran, prestasi belajar, atau self efficacy siswa kelas XI IPA ditinjau dari KKM. (2) pembelajaran model CORE strategi berpasangan pada materi geometri transformasi efektif ditinjau dari kemampuan penalaran, prestasi belajar, atau self efficacy siswa kelas XI IPA ditinjau dari KKM. (3) tidak terdapat perbedaan keefektifan antara model CORE strategi kelompok kecil dan strategi berpasangan pada materi geometri transformasi ditinjau dari kemampuan penalaran, prestasi belajar, dan self efficacy siswa kelas XI IPA. (4) keefektifan model CORE dalam meningkatkan prestasi belajar dipengaruhi oleh kompleksitas materi pembelajaran. Berdasarkan keempat simpulan tersebut, dapat diketahui bahwa pengelompokan dalam pembelajaran model CORE dapat dibentuk antara 2-6 siswa pada setiap kelompoknya, karena perbedaan 
keefektifan dikarenakan bukan karena strategi pengelompokan, baik kelompok kecil maupun berpasangan, namun karena kompleksitas materi pembelajaran.

Hasil penelitian ini menambah bukti empiris bahwa strategi pengelompokan dan kekompleksan materi dapat menentukan keberhasilan pembelajaran model CORE. Selain itu, diperoleh bukti empiris bahwa pembelajaran model ini dapat mengembangkan/meningkatkan kemampuan penalaran, prestasi belajar matematika, dan self efficacy siswa, maka guru dapat menjadikan pembelajaran model CORE strategi kelompok kecil atau strategi berpasangan sebagai salah satu alternatif pembelajaran matematika. Beberapa hal yang perlu dilakukan agar memperoleh hasil yang maksimal pada saat menggunakan model pembelajaran CORE diantaranya merancang LKS sesuai dengan langkah model pembelajaran CORE serta membentuk kelompok yang terdiri dari 2-6 siswa dengan anggota yang heterogen agar proses pembelajaran dengan model CORE dapat lebih baik sehingga dapat mengembangkan self efficacy siswa.

\section{UCAPAN TERIMA KASIH}

Ucapan terima kasih disampaikan kepada semua pihak yang telah membantu terlaksananya penelitian ini.

\section{DAFTAR PUSTAKA}

Al-humaira, F., Suherman, \& Jazwinarti. 2014. Penerapan Model Pembelajaran CORE pada Pembelajaran Matematika Siswa Kelas X SMAN 9 Padang. Jurnal Pendidikan Matematika, 3 (1), 31-37.

Albab, I. U., Hartono, Y., \& Darmawijoyo, D. 2014. Kemajuan Belajar Siswa pada Geometri Transformasi Menggunakan Aktivitas Refleksi Geometri. Jurnal Cakrawala Pendidikan, XXXIII(3), 338 - 348.

Azwar, S. 2015. Tes Prestasi. Yogyakarta: Pustaka Belajar.

Bandura, A. 1997. Self Efficacy: the Exercise of Control. New York, NY: W.H. Freman Company.

Beladina, N.,Suyitno, A., \& Kusni.2013. Keefektifan Model Pembelajaran Core Berbantuan
LKPD terhadap Kreativitas Matematis Siswa. Unnes Journal of Mathematic Education, 2(3), 34-39.

Bieda, K. N., Ji, X., Drwencke, J., \& Picard, A. 2013. Reasoning-and-Proving Opportunities in Elementary Mathematics Textbooks. International Journal of Educational Research, 9 (46), 1-10.

Bruning, R. H., Schraw, G. J., \& Norby, M. M. 2011. Cognitive Psychology an Instruction. Boston, MA: Pearson Education, Inc.

Calfee, R., Curwen, M. S., Miller, R. G., \& Smith, K. A. W. 2010. Increasing Teacher's Metacognition Develops Students' Higher Learning During Content Area Literacy Instruction: Finding from the Read-Write Cycle Project. Issues in Teacher Education, 19(2), 127-149.

Chambers, P. 2008. Teaching Mathematics Developing as a Reflective Secondary Teacher. London, UK: SAGE.

Cohen, E. 1994. Restructuring the Classroom: Conditions for Productive Small Groups. Review of Educational Research, 64 (1), 1-35.

Dzhogleva, H., \& Lamberton, C.P. 2014. Should Birds of a Feather Flock Together? Understanding Self-Control Decisionsin Dyads. Journal of Consumer Research, pp. 000.

Gillies, R.M. 2003. Structuring Cooperative Group Work in Classrooms. International Journal of Educational Research, 39 (1), 35-49.

Johnson, B. \& Christensen, L. 2014. Educational Research: Quantitative, Qualitative, and Mixed Approaches ( $3^{\text {rd }}$ ed.).California, CA: SAGE.

Kirschner, F., Paas, F., \& Kirschner, P.A. 2010. Task Complexity as a Driver for Collaborative Learning Efficiency: the Collective Working-Memory Effect. Applied Cognitive Psychology, 25 (1), 615-624. 
Kirschner, P.A., Sweller, J., \& Clark, R.E. 2006. Why Minimal Guidance During Instruction Does not Work: an Analysis of the Failure of Constructivist, Discovery, ProblemBased, Experiential, and Inquiry-Based Teaching. Educational Psychologist, 4 (2), 75-86.

Latane, B., William, K., \& Harkins, S. 1979. Many Hand Make Light the Work: the Causes and Consequences of Social Loafing. Journal of Personality and Social Psychology, 37 (6), 822-832.

Lefrancois, G. R. 2000. Psychology for Teaching. Belmont, CA: Wadsworth.

Maltby, J., Day, L., \& Macasskill, A. 2010. Personality, Individual Differences and Intelligence. London, UK: Pearson.

McKinley, J. 2010. Raising black student achievement through culturally responsive teaching. Alexandria, VA: ACSD.

Muslih, M. 2011. KTSP Pembelajaran Berbasis Kompetensi dan Kontekstual. Jakarta: Bumi Aksara.

Muslimin, Z.I. 2012. Prestasi Belajar Mahasiswa Ditinjau dari Jalur Penerimaan Mahasiswa Baru, Asal Sekolah, dan skor Tes Potensi Akademik. Jurnal Penelitian Psikologi, 3(1), 381-393.

NCTM. 2000. Principles and Standars for School Mathematics. Reston, VA: NCTM.

Niken, Susanto \& Setiawan, T.B. 2012. Penerapan Pembelajaran Matematika Melalui Model Pembelajaran Reciprocal dalam Mengatasi Kesalahan Siswa Menyelesaikan Soal Matematika Kelas IX SMP N 1 Pakusari Pokok Bahasan Statistika Semester Ganjil Tahun Ajaran 2012/2013. Kadikma, 3 (3), 95-108
Putri, R. I. 2014. Keefektifan Strategi REACT Ditinjau dari Prestasi Belajar, Kemampuan Penyelesaian Masalah, Koneksi Matematis, self efficacy. Jurnal Riset Pendidikan Matematika, 2 (2), 262-272.

Retnowati, E. (2012). Learning Mathematics Collaboratively or Individually. $2^{\text {nd }}$ International STEM in Education Conference, Beijing, 335-339.

Saputra, R. P. 2016. Pembelajaran Geometri Berbantuan Geogebra dan Cabri Ditinjau dari Prestasi Belajar, Berpikir Kreatif dan SelfEfficacy. Phytagoras: Jurnal Pendidikan Matematika, 11 (1), 59-68.

Schunk, D. H. 2012. Learning theory (6 ${ }^{\text {thed. }}$.). Boston, MA: Pearson.

Sengul, S. 2011. Effects of Concept Cartoons on Mathematics Self Efficacy of $7^{\text {th }}$ grade Students. Educational Sciences: Theory \& Practice, 11(4), 2305-2313.

Soule, H., \& Wesolowski, K. 2011. P21 Common Core Toolkit. Tucson: Edleader.

Steenbeek, H.W., \&Geert, P.L.C. 2006. A Theory and Dynamic Model of Dyadic Interaction: Concerns, Appraisals, and Contagiousness in a Developmental Context. Science Direct Article in Press, 6 (1), 1-40.

Steinbring, H. 2005. The Construction of New Mathematical Knowledge in Classroom Interaction an Epistemological Perspective. New York, NY: Springer.

Syah, M.1995. Psikologi Pendidikan Suatu Pendekatan Baru. Bandung: Rosdakarya.

Undang-Undang Republik Indonesia Nomor 20 Tahun 2013, tentang Sistem Pendidikan Nasional.

Westwood, P.S. 2009. What Teachers Need to Know About Teaching Methods. Camberwell, Victoria: ACER. 